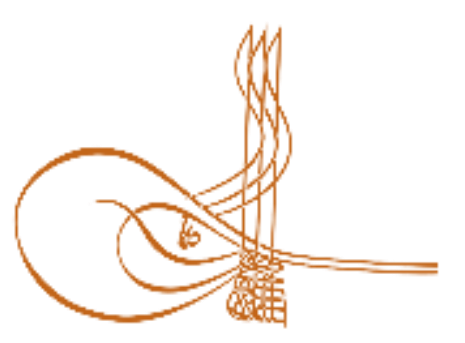

www.turkishstudies.net/turkishstudies
Turkish Studies

eISSN: $1308-2140$

Research Article / Araştırma Makalesi

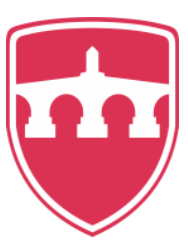

INTERNATIONAL

BALKAN

UNIVERSITY

Sponsored by IBU

\title{
Siyasal İkna: 23 Haziran 2019 İstanbul Yerel Seçiminde Adayların Facebook Kullanımı
}

Facebook Use of Politicians As A Persuasion Media: Istanbul Local Election on 23th. of June 2019

\author{
Tuğba Akdal ${ }^{*}$
}

\begin{abstract}
For political parties and politicians, who want to govern the society, introducing themselves and their ideas to constituents as to convince them that they are the best alternative has become the most important element of politics as to be chosen together with existence of democratic governance. Interaction feature of social media provides politicians with countless alternatives to communicate with constituents as to tell and persuade them about themselves and their intentions. In the study, it was aimed to evaluate the posts shared by Binali Yıldırım, the candidate of the Republic Alliance consisting of the Justice and Development Party and the Nationalist Movement Party and the posts shared by Ekrem İmamoğlu, the candidate of the Nation alliance consisting of the Republican People's Party and the IYI Party between 16-23 June 2019 for the local elections of Istanbul on 23 June 2019, within their political communication campaigns through their personal accounts on Facebook. According to the data obtained as a result of the analysis made in this study, both candidates concentrated more on the content such as photos and videos in their Facebook posts rather than long timeline texts. According to the FAGEO assessment conducted in the study, despite Binali Yildırım had fewer followers than Ekrem İmamoğlu, he was more successful than Ekrem İmamoğlu with respect to the interaction rate. However, despite the fact that Ekrem İmamoğlu had more reach due to the greater number of followers when compared to that of Binali Yildırım, he was unable to reflect this superiority of the number of followers to the rate of reach at the same rate. In the light of these findings, it can be stated that the increase in the number of Facebook followers affects the increase in the rate of exposure of the relevant followers to the message in the news feed; and this increases the potential for reach and, accordingly, interaction.
\end{abstract}

\section{Structured Abstract: Introduction}

The subject of this study is to reveal how Facebook, as one of the most important social media tools used in political communication in the world, was used by the candidates of the Republic and Nation alliances for the political communication campaigns in the local elections of Istanbul on June 23rd, 2019 and to analyze the achievement levels of these candidates in interacting with the target audiences and/or voters.

\footnotetext{
* Dr. Öğr. Üyesi Zonguldak Bülent Ecevit Üniversitesi, İletişim Fakültesi, Halkla İlişkiler ve Tanıtım Bölümü Asst Prof. Dr. Zonguldak Bülent Ecevit University, Communication Faculty, Public Relations and Publicty Department ORCID 0000-0002-6964-035

tugbaakdal@outlook.com

Cite as/ Atıf: Akdal, T. (2020). Siyasal ikna: 23 Haziran 2019 İstanbul Yerel Seçiminde adayların Facebook kullanımı, Turkish Studies, 15(2), 683-702. https://dx.doi.org/10.29228/TurkishStudies.42088

Received/Geliş: 10 March/Mart 2020

Accepted/Kabul: 25 April/Nisan 2020

Copyright (C) MDE, Turkey
} 


\section{Purpose}

In the study, it was aimed to evaluate the posts shared by Binali Yildırım, the candidate of the Republic Alliance consisting of the Justice and Development Party and the Nationalist Movement Party and the posts shared by Ekrem İmamoğlu, the candidate of the Nation alliance consisting of the Republican People's Party and the IYI Party between 16-23 June 2019 for the local elections of Istanbul on 23 June 2019, within their political communication campaigns through their personal accounts on Facebook.

For this basic purpose, the following research questions were sought:

- $\quad$ Q1: Does the number of followers on Facebook reflect the achievement of reach and interaction at the same level?

- Q2: Is the persuasion theory of Aristotle, which consists of the elements of Ethos, Pathos and Logos, effectively used in political communication?

\section{Method}

Facebook is the most analyzed platform in social media interaction research to understand interaction; and Popularity Interaction is measured through metrics consisting of the number of likes, comments and followers as well as the length of the timeline (Rapp et al. 2013, cited by Perrealut and Mosconi, 2018: 3573). In this study, the number of shares metric was included in the analysis instead of the length pf the timeline specified in the Popularity Interaction approach. According to this approach, which is called The Average Engagement Rate Per Post on Facebook (FAGEO), the total number of posts, likes and comments obtained during the period of analysis should be divided by the number of posts and the followers. Obtaining a result around the level of $1-2 \%$ is accepted as successful (Örnek, 2016).

The research was based on the evaluation and comparison of the interaction success achieved by the candidates of the two alliances through their posts in terms of certain metrics such as the number of emotional notifications such as the likes of Facebook users and/or voters, the number of comments made on the posts, the number of followers of their personal pages on Facebook using the FAGEO (Average Post Engagement Rate), and on the analysis of the persuasion strategy that the candidates used i to obtain these interaction results $\mathrm{n}$ their political communication campaigns through rhetorical analysis of one post from each candidate that received the highest emotional sharing within the aforementioned timeframe.

\section{Results}

According to the data obtained as a result of the analysis made in this study, both candidates concentrated more on the content such as photos and videos in their Facebook posts rather than long timeline texts. According to the FAGEO assessment conducted in the study, despite Binali Y1ldirım had fewer followers than Ekrem İmamoğlu, he was more successful than Ekrem İmamoğlu with respect to the interaction rate. In contrast, the achievement of Ekrem Imamoglu in reach was higher than that of Binali Yıldırım because of the fact that Ekrem İmamoğlu had more followers on Facebook. Also, according to the algorithm of Facebook, as the number of reach and interaction rates of a post increases, they are prioritized in the (news feedsof the users when compared to other posts; and naturally it is ensured that they are viewed more by the users. It may be thought that this could provide an advantage to the candidate with more followers; however, despite the fact that Ekrem İmamoğlu had more reach due to the greater number of followers when compared to that of Binali Yildırım, he was unable to reflect this superiority of the number of followers to the rate of reach at the same rate.

In the light of these findings, it can be stated that the increase in the number of Facebook followers affects the increase in the rate of exposure of the relevant followers to the message in the news feed; and this increases the potential for reach and, accordingly, interaction. Although these findings show that there is a linear relationship between the number of followers, the rate of reach and interaction on Facebook, it also indicates that the increase in the number of followers does not mean and does not guarantee that the interaction rate increases at the same rate. The increase in this direction can be achieved by politicians through sharing photos, videos, and especially visual content such as live broadcasts in line with the expectations of their followers so that they could attract their attentions. In addition, it was determined in the research that voters on Facebook showed much more interest in live broadcasting than video sharing. However, the reach of each live broadcast by Binali Yildirım to approximately twice the number of his followers is important in terms of revealing that the voters are highly interested in live broadcasts even if they

Turkish Studies, 15(2) 
do not follow the candidate. It was observed that both candidates used the elements of Aristotle's persuasion theory in different ways within their political communication.

As a result, in the information age we live in, it has become very easy for politicians to reach voters anytime and anywhere, and to inform and persuade them on party ideologies and political issues through the internet and social media. Facebook, in particular, stands out as a very important tool in political communication, as it provides the opportunity to make the voices of voters heard by enabling them to participate in politics by providing them with a platform for discussion as an e-public space due to the large number of its users and the interactive environment. It is the key to political communication success that political actors adopt an interactive political communication through social media environments such as Facebook, which reflect the dynamics of the age, and make them an important part of political communication and persuasion strategies instead of the traditional political communication action based on a one-way message transfer. It is also important for politicians to demonstrate that they care about the participation of their voters in the political process and even show that their political messages are shaped by the feedback they receive from these environments.

Keywords: Political communication, persuasion, new media, facebook, post engagement rate

Öz: Demokratik yönetim şeklinin var olması ile birlikte toplumların ideal bir şekilde yönetilmesi ve bu konuda yönetime talip olan siyasi partilerin ve siyasetçilerin seçilebilmek amaciyla kendilerinin ve düşüncelerinin en iyi alternatif olduğunu seçmenlere anlatabilme çabaları ön plana çıkmış, bu nedenle iletişim ve ikna çalışmaları politikanın vazgeçilmez unsurları haline gelmiştir. Sosyal medya sayesinde her an ve yer yerde seçmenleri ile anlık etkileşime geçebilen siyasiler, kendilerini ve icraatlerini seçmenlere anlatma hususunda ve onları bu konularda ikna edebilmekte sayısız firsatlar ve kolaylıklar elde etmişlerdir. Araştırmada Adalet ve Kalkınma Partisi ve Milliyetçi Hareket Partisi'nin oluşturduğu Cumhur ittifakı adayı Binali Yıldırım ve Cumhuriyet Halk Partisi ve İyi Parti’nin oluşturduğu Millet ittifakının adayı Ekrem İmamoğlu'nun 23 Haziran 2019 İstanbul yerel seçimine yönelik 16-23 Haziran 2019 tarihleri arasındaki sosyal medya araçlarından Facebook'taki kişisel hesaplarında yer alan siyasal iletişim kampanyalarına yönelik paylaşımlarının değerlendirilmesi amaçlanmıştır. Bu araştırmada yapılan inceleme sonucunda elde edilen verilere göre her iki adayın da Facebook paylaşımlarında uzun duvar yazılarından ziyade fotoğraf ve video gibi içeriklere daha fazla ağırlık vermektedir. Çalışmada gerçekleştirilen FAGEO değerlendirmesine göre, Binali Yıldırım'ın Ekrem İmamoğlu'ndan daha az takipçisi olmasına karşın, etkileşim (interaction) oranında Ekrem İmamoğlu'na göre daha başarılı olduğu tespit edilmiştir. Fakat Ekrem İmamoğlu, araştırmamıza konu olan bir hafta içerisinde rakibi Binali Yıldırım'dan paylaşımlarının ortalamasında sayıca fazla olan takipçileri nedeniyle daha fazla erişim sayısına ulaşmasına rağmen, takipçi sayısı üstünlüğünü erişim sayısına aynı oranda yansıtamamıştır. Bu bulgular ışı̆̆ında, Facebook takipçi sayısındaki artışın, ilgili takipçilerin haber akışında mesaja maruz kalma oranındaki artışa etki ettiği ve bunun da erişim ve buna bağlı olarak da etkileşim potansiyelini yükselttiği ifade edilebilir.

Anahtar Kelimeler: Siyasal iletişim, ikna, yeni medya, facebook, gönderi etkileşim oranı

\section{Giriş}

"Bugünlerde gerçek; gerçek olan değil, başkalarının inanmaya ikna ettiğidir" (Montaigne, 2017: 26). Toplumların yönetimi söz konusu olduğundan beri yönetenler ve/veya siyasi erk, yönetilenlerle yani seçmenleriyle iletişim içinde olmaya çalışarak, toplumun geleceği adına iyi şeyler yapacakları konusunda kitlelerin kendilerine güvenini oluşturmak ve hedef kitlelerini ikna etmek yoluyla kendilerini desteklemelerini sağlamak adına motive etmeye çalışmışlardır. Demokratik yönetimlerde siyasilerin kendileri ve yapacakları çalışmalar hususunda kamuoyunun rızasını alabilmeleri ancak onları ikna edebilmek ve bu sayede desteklerini elde edebilmek ile mümkün olabilmektedir. Söz konusu bu desteğin kamuoyunu ikna ederek sağlanması, demokrasilerin özünü oluşturan seçmenlerin iradelerini sandıklara yansıtması anlamına gelmekte ve siyasiler yönetilenleri yönetebilmek için belirli sürelerle seçilmektedir. Bunun gerçekleşmesini sağlayan ise yönetime talip olan siyasilerin seçmenlere kendilerini anlatabilmeleri için 
geliştirdikleri çeşitli stratejiler ve bu stratejilerin ikna edici bir biçimde işlemesine yardımcı olan siyasal iletişimdir.

İnsanların duyduklarından çok gördüklerine inanmaları nedeniyle görünürlük, siyasal iletişim ve iknanın en önemli unsurları arasında yer almaktadır. "İkna etmekten başka yönetim şeklinin kabul görmeyeceği günümüz toplumlarında, siyasiler, iktidar olmada ve iktidarlarını sürdürmede birçok farklı yol, yöntem ve teknikler denenmiş ve denemeye de devam etmektedirler" (İnce, 2016: 449). "Tek bir görüntü binlerce kelimeden daha etkilidir" (Konfüçyüs, 2016: 7). Yönetenler siyasal iletişim faaliyetlerini günümüzde genellikle kitle iletişim araçları üzerinden gerçekleştirmekte olup, kitle iletişim araçlarından önce yönetenlerin bunu gerçekleştirebilmelerinin tek yolu, özel günlerde halkın içerisinde bulunmak ve kendilerini onlara bu sayede görünür kılmaya çalışmakken, kitle iletişim araçlarının ortaya çıkması sonucunda zaman ve mekanda genişlemenin sağlanması ile birlikte çok daha fazla kişiye çok kısa bir zaman içerisinde ve hatta anlık olarak ulaşarak görünür olabilmek olanaklı hale gelmiştir. Özellikle yazılı basından farklı olarak radyonun duyu organlarından kulak aracılığ 1 ile başlayan geniş kitlelere hitap edebilme kolaylığı, televizyon ile birlikte hem kulak hem de göze hitap edilebilecek boyuta ulaşmış, bu sayede ise siyasal iletişimde yepyeni bir dönem başlamıştır. İçinde bulunduğumuz internet çağında ise iletişim bu zamana kadarkinden çok daha hızlı ve etkileşime açık bir hale bürünmüş ve hedef kitlelerle anlık, interaktif ve mobil etkileşim kurulabilmesi, yönetilenleri ikna etmek adına siyasilere sonsuz firsatlar ve kolaylıklar sunmuştur. Özellikle web 2.0 teknolojisi ile birlikte internet altyapısı üzerinde çalışan sosyal medya araçlarının etkileşimli ortamı demokrasinin gereği olan katılımcılığ 1 ve temsiliyeti oldukça geliştirmiş ve sanal ortamdaki mikro blogların ve çevrimiçi gazetelerin ekamusal alan olarak işlev görmeye başlaması ile seçmenlerin kendi geleceklerini ilgilendiren konular hakkında hem daha çabuk ve detaylı olarak birinci elden bilgilendirilmeleri sağlanmış ve hem de ilgili konularda kendi fikirlerini beyan etmelerine imkan tanınarak diğer seçmenlerle karşılıklı tartışmalara katılabilmelerinin önü açılmıştır. Bu ortamlarda yönetilenlerin siyasi konulardaki geri bildirimleri politikacıların önceliklerini ve buna bağlı olarak stratejilerini belirlemelerini sağlamakta ve bunun sonucunda da kendilerini çok daha etkili şekilde kitlelere anlatabilmeleri ve onlarla bire bir etkileşime geçmeleri suretiyle de ikna edebilme potansiyelinin yüksek olması mümkün hale gelmektedir.

Politikacılar için televizyon ile başlayan ekranda görünürlük sayesinde evlere konuk olma ayrıcalığı, çoklu medya özellikli bilgi iletişimi teknolojisinin akıllı cihazları sayesinde mobil hale gelmiş ve yönetenlerin ve/veya yönetime talip olan politikacıların seçmenlerine anlık olarak her an her yerde ulaşabilmelerini sağlamıştır. Mobil cihazlar aracılığıyla ulaşılan ve onlar için üretilen içeriklerin hayatın içinden olma özelliğini daha iyi yansıtması ve bu nedenle kullanıcılar tarafından çok daha doğal olarak algılanması, siyasilere seçmenlerini kendilerine ve gerçekleştirecekleri icraatlarına ikna etmek için daha fazla alternatifler sunmaktadır. Ancak bununla beraber internetin yönetilenlere de çeşitli imkân ve kolaylıklar sunduğunu ifade etmek gerekir. İnternet sistemi seçmenlere, siyasilere anında ulaşma imkânı vermiş, görüş ve önerilerini muhatapları ve diğer insanlarla paylaşmalarını mümkün kılmış, ayrıca bireysel iş ve işleyişin kolaylaşmasına da imkân sağlamıştır. Örneğin; internet, devletin ise e-devlet ve m-devlet gibi uygulamalarla vatandaşlarına hizmet için her yerde olmasını sağlayarak, onları hizmetlerden yararlanmak adına devlet binalarına gelmek zorunda bırakmadan her an, her yerde devlet hizmetlerine ulaşabilmelerini olanaklı hale getirmiştir. İnternet ve internet destekli mobil cihaz kullanımı, gündelik yaşamda bireylere sunduğu olanaklar ve kolaylıkların da etkisiyle çok kısa zamanda kabul görmüş ve oldukça yaygınlaşmıştır. We are social 2019 y1lı Türkiye verilerine göre, nüfusu 82,44 milyon olan Türkiye'de 59,36 milyon internet kullanıcisı bulunmakta olup, aktif sosyal medya kullanıcı sayısı ise 52 milyon'dur. Aktif mobil internet kullanıcı sayısı ise 56,03 milyondur. Mobil cihaz kullanan yetişkinlerin oranı \%98, mobil cihaz kaydı olanların sayısı ise 76,34 milyondur. Bunların 44 milyonunu ise aktif mobil sosyal medya kullanıcıları oluşturmaktadır. Mobil cihaz kullananların \%77'si akıllı cihaz kullanmaktadır. Yetişkinlerin \%99'unun televizyonu vardır (Nurluoğlu, 2019). Oranlara 
bakıldığında mobil iletişim cihazlarının kullanımının televizyon kullanımını yakalamış olması, bu cihazların kullanımının oldukça yaygınlaştığını vurgulaması açısından dikkat çekicidir. İnternetin bu denli yaygın kullanımı seçmenlere her an her yerde ulaşılabilmesini daha olanaklı hale getirdiği için ve zaman mekân kavramlarının tüm sınırlılıklarıyla beraber eriyip gitmeye başlaması sebebiyle, internet ve internet destekli bilgi iletişimi teknolojisi cihazları siyasal iletişim çalışmalarının vazgeçilmez araçları haline gelmiştir. İnternet ortamının sunduğu kullanım olanaklarına her gün bir yenisinin eklenmesine karşın Facebook, siyasal iletişim alanında hem partiler hem de seçmenler için hala güncel konumunu korumaktadır. Bu çalışmada da Cumhur ve Millet ittifakı adaylarının 23 Haziran 2019 İstanbul Yerel Seçimlerinde siyasal seçim kampanyalarının bir parçası olarak kişisel Facebook sayfalarını nasıl kullandıkları değerlendirilmiş ve bu adayların hedef kitlelerle ve/veya seçmenlerle Facebook üzerinden etkileşime geçme başarıları analiz edilmeye çalışılmıştır. Araştırmada; "Facebook'ta sahip olunan takipçi sayısı erişim ve etkileşim başarısını aynı oranda yansımakta mıdır ve Aristo'nun Ethos, Pathos ve Logos unsurlarından oluşan ikna kuramı siyasal iletişimde etkin olarak kullanılmakta mıdır?" sorularına yanıt aranmış, adayların Facebook erişim ve etkileşim başarısı paralellikleri, Facebook'un Averaj Gönderi Etkileşim Oranı (FAGEO) olarak adlandırılan Popülerlik Etkileşimi yaklaşımı bağlamında tespit edilmeye çalışılmıştır.

\section{Siyasal İletişim ve İkna'nın Yeni Bir Yüzü Olarak Sosyal Medya}

Her politik parti ve aktörün özellikle seçim dönemi öncesinde seçmen kitlelerini kendilerine çekme ve bu yolla seçim rekabetinden başarıyla ayrılma amacına hizmet eden tüm girişim ve çabalarının temelini oluşturan ikna faaliyetleri, bir dizi iletişim etkinliği ile birlikte yürütülmektedir. Bunlardan ikna amaçlı kitle iletişimi, çok sayıda insanın iletişimcinin bakış açısına inanmasını ve o yönde harekete geçmesini teşvik etmeyi hedefler ve özellikle hükümetler, pazarlamacılar ve seçmenleri harekete geçirmek için siyasi partiler tarafindan kullanılır (Matz vd., 2017: 12714). Parti liderlerinin ve diğer politik aktörlerin seçim öncesi ve sonrası dönemde seçmenlerle kurduğu iknaya dayalı bu sistemli etkileşimler ise 'siyasal iletişim' olarak adlandırılmaktadır. "Siyasal iletişim kavramı çok basite indirgenerek, belli ideolojik amaçlarını, toplumda belli gruplara, kitlelere, ülkelere ya da bloklara kabul ettirmek ve gerektiğinde eyleme dönüştürmek, uygulamaya koymak üzere siyasal aktörler tarafindan çeşitli iletişim tür ve tekniklerinin kullanılması ile yapılan iletişimdir" (Aziz, 2003: 3). Bu açıklamalarda da vurguladığı gibi çoğunlukla siyasal kesimden seçmenlere doğru gerçekleşen siyasal iletişim faaliyetlerinin amaçlarının en başında seçmenlerin ikna edilmesi yer almaktadır. Bu nedenle, ikna ve iletişimin birbirini tamamlayan iki olgu olduğunu söylemek mümkündür. Siyasal iletişim alanında önemli bir yere sahip olan iknanın başarısı için yukarıda anlatılan yöntem ve adımların hangisi ya da hangilerini takip etmesi gerektiğini parti ve aktörlere gösteren ise, yine iletişimin kendisi olmaktadır. Siyasal iletişim sayesinde parti ve aktörler seçmen kitlelerine kendi siyasal mesaj ve vaatlerini aktarırken aynı zamanda da seçmenlerin sosyo-demografik ve sosyo-psikolojik durumları hakkında bilgi sahibi olabilmektedirler. Yani seçen ile seçilen arasında bir köprü vazifesi gören ve temelinde ikna amacı yatan siyasal iletişim, siyasilerin ikna faaliyetleri planlamasında ihtiyaç duyduğu bilgileri sağlaması suretiyle de iknanın yol haritasını ve başarı grafiğini belirleme ve etkileme gücü ve konumuna erişmektedir. Siyasal iletişimin temelinde yönetme gücüne erişmek isteyen parti ve aktörlerin seçmen kitleleriyle bir yandan duygusal ve ideolojik bir bağ kurma arzusu, diğer yandan ise bu kitleleri etkileyip, ikna ederek yönlendirme eğilimi yer almaktadır. Siyasal iletişim, parti ve aktörlerin çeşitli iletişim tür ve teknikleriyle seçmenler üzerinde gerçekleştirdiği ikna çalışmaları olarak da adlandırılmaktadır. Bu değerlendirme sonucunda ise ikna faaliyetlerinin siyasal iletişim zemini üzerine kurulduğu ve her iki olgunun da birbirinin başarısını etkilediği söylenebilir.

Siyasal ikna ise bir siyasi parti ya da politik bir aktörün kendine ait tutumları, eğilimleri, ideolojileri, kısa ve uzun vadeli planlamaları ve beklentileri doğrultusunda seçmen kitlelerinin duygu, düşünce, tutum ve davranışlarını etkilemesi, yönlendirmesi ve ideolojiler bağlamında ortaya 
konan girişim ve mücadelelerin haklılığına inandırması için gerçekleştirilen planlı iletişim çalışmaları olarak tanımlanabilir. "İkna kavramının temel şartları arasında, bilinçli bir niyet ya da girişimin bulunması, motivasyon, bireyin hareketinin yönünü tayin etme ya da manipülasyon, davranışı değiştirme, biçimlendirme ya da etkileme ile tüm bunları gerçekleştirebilecek mesajların nakledilmesini saymak mümkündür" (Özkan, 2004: 156). Genel anlamda iknanın olduğu gibi, siyasal iknanın temeli de başta hedef kitlelere erişime ve onlarla sağlanan etkileşime dayanmaktadır. Genellikle politik aktörlerden seçmenlere doğru gerçekleşen siyasal iletişim eylemlerinin neredeyse hepsi ikna amacı gütmektedir. İkna amacı güden bir siyasal iletişimin başarısı; seçmenlerden oluşan hedef kitlenin anlamlandırma pratiklerine göre kodlanmış siyasi mesajın doğru zamanda, doğru hedef kitleye, doğru kanalla, doğru süre ve tekrar ile iletilmesinin detaylı bir şekilde planlanmasına bağlıdır. Tüm bu unsurların istenilen etkiyi yaratabilmesinin güvence altına alınması, özenli bir kontrol ve ölçmeyi gerektirir. Bu sayede mesajın istenilen ikna etkisini yaratabilmesi sağlanırken, gerekli düzeltici ve önleyici önlemlerin zamanında alınması yoluyla da mesajların etkililiği artırılabilir. Aksi halde siyasal iletişim eylemi politik kesimden seçmenlere doğru uzanan tek yönlü bir (asimetrik) bilgi akışıyla sınırlı kalacak ve asıl olması gereken çift yönlü (simetrik) etkileşim sağlanamayacaktır. Siyasal iletişim eyleminde etkileşimin sağlanabilmesi bazı hususlardan ötürü önemlidir; ilk olarak seçmenlerin gelen mesajlara olumlu ya da olumsuz biçimde gerçekleştirdiği geri dönüşler, politik aktörlerin seçmenleri istek, beklenti ve şikayetleriyle birlikte daha fazla tanıması potansiyelini artırmaktadır. İkinci olarak politik aktörlerin, artan etkileşim sayesinde seçmenleri nasıl ve ne ölçüde ikna edebildiklerini ve iknaya yönelik daha fazla neler yapabileceklerini öğrenme şansı elde ettiği ifade edilebilir. Siyasal iletişimde etkileşime dayalı web 2.0 teknolojisi destekli sosyal medya araçları, seçmen nabzının sürekli olarak tutulmasına imkân tanıyarak ikna stratejilerinin yenilenmesi ve geliştirilmesinde politikacılara ciddi katkılar ve firsatlar sunmaktadır.

Politik aktörlerin seçmenlerde istedikleri etkiyi ve davranış değişikliğini yaratarak kendilerine oy verilmesi ile seçilmelerini sağlamak için öncelikli olarak hitap ettikleri hedef kitlenin özelliklerini bilmesi, yani iletişime geçerek ikna etmek istedikleri seçmen kitlelerini ve onların sorunlarını oldukça iyi tanıyor olmaları gerekmektedir. Bu, ikna faaliyetlerinde bilinçli adım ve girişimlerin temeli sayılabilecek siyasal iletişim planlarının yapılabilmesi için temel koşul yerine konabilecek bir husus olup sistemli ve sürekli bir araştırmayı gerektirir. İletişim ve iknanın başarı ölçütü olarak nitelendirilebilecek bu hususun karşılanabilmesi için ikna faaliyetlerinin ön çalışmasını kamuoyu araştırmaları oluşturmakta ve bu araştırmalarda seçmenlerin politik görüşleri, eğilimleri, talep ve beklentileriyle ülke gündemi hakkındaki bilgi ve farkındalık seviyeleri ölçülmeye çalışılmaktadır. Hitap edilen hedef kitlenin sık sık takip edilmesi sayesinde seçmenler ile ilgili en güncel bilgilere sahip olunmasının politik parti ve aktörlere sağladığ yarar ise siyasal iletişimde etkili mesajların oluşturulması ve iletişim kanallarının seçilmesi aşamasında ortaya çıkmaktadır ki bu aşama planlama aşamasıdır. İkna edici politik mesajların herkese hitap edecek şekilde kurgulanması, açık ve anlaşılır olması, dikkat çekmesi ve en önemlisi de etki altına alınmak istenen seçmen kitleleriyle siyasiler arasında ortak bir payda ve bir bağ kurulabilmesine katk1 sağlaması ve mesajın etkileyici bir şekilde aktarılması gerekmektedir. Bu hususun başarılabilmesi için bu konuda en önemli stratejilerden biri olarak kabul edilen ve Aristo ve Cicero'nun en önemli temsilcileri olarak kabul edildiği iknaya yönelik retorik (güzel söz söyleme, hitabet) sanatının, mesajın kaynağı olarak siyasiler tarafından en iyi şekilde kullanılabilmesi gerekir. Özellikle antik Roma'dan beri ikna için kullanılan retorik, haftalık dergiler ve daha sonra da gazeteler gibi basılı materyaller sayesinde yazının zaman ve mekânda genişlemesinin sağlanmasıyla birlikte kitleleri etkilemede onun gölgesinde kalmıştır. Televizyonun icadı ile birlikte yazının avantajına sesli görselliğin de erişmesiyle politikacılar için iknada retoriğin önemi tekrar artmıştır. Günümüzde ise internet ve onun alt yapısında çalışan Facebook gibi sosyal medya ortamları sayesinde yazı, ses ve görüntü paylaşımı mobil hale gelmiş, bu nedenle bu ortamlar siyasetçiler için özenle yönetilmesi gereken, fark yaratılabilecek en önemli iletişim araçları haline gelmiştir. Söz konusu bu ortamlarda 
başta gençler olmak üzere her yaş grubundan seçmenlere her an mobil olarak ulaşabilmek, bu ortamda onları etkileyebilmek ve ikna edebilmek için görünürlükle birlikte hitabet sanatı olan retoriğin de siyasetçiler için önemini oldukça artırmıştır. 'Ethos, Pathos ve Logos' adı verilen unsurlarından oluşan Aristo'nun retorik sanatına yönelik yaklaşımında 'Ethos', hitap eden kişinin güvenilirliği ve uzmanlığına; 'Pathos', mesajın alıcılarıyla kurulması gereken mental ve duygusal etkileşime; 'Logos' ise iletişimi yapılan mesaja ait argümanların ve/veya delillerin gücüne vurgu yapmaktadır. Cicero'ya göre ise (Berger, 2000: 54) retorik beş önemli unsuru kapsar: Ne söyleneceğini belirleme, düzenleme, tarzı belirleme, hafızada muhafaza etme ve en çekici ve etkili şekilde mesajı alıcısına aktarma.

Tüm bunların yanı sıra seçmenlere gönderilen mesajların betimleyicilik özelliğine sahip olması ve seçmenlere umut vaat eden hayaller kurdurabilmesi, istenen etki ve değişimin daha kolay sağlanabilmesinin yolunu açmaktadır. Netice itibariyle içerikleri anlaşılır olmayan, mesajlarda kendinden bir şeyler bulamayan, sorunlarının ve beklentilerinin anlaşıldığını düşünmeyen ve dolayısıyla kendisine seslenen politik aktör ile bağ kuramayan seçmenlerin beklenen düşünce ve davranış değişikliğini de yerine getirmesi beklenemez. Bu yüzdendir ki siyasal iletişim ve seçim kampanya çalışmalarında her parti ve aday siyasi aktörün gönderdikleri mesajlar genellikle ülkedeki mevcut durum hakkında bilgi vermeye yönelik iken, aynı zamanda içinde bulunulan durumdan çok daha iyisini sunmayı vaat etmekte ve bu yönde beklenti oluşturularak seçmenlerde istenilen doğrultuda fikir veya davranış değişikliği yaratmaya ilişkin motivasyon eğilimleri ortaya konmaktadır. Anık'a göre, siyasal motivasyonun kilit unsurları; gerginlik ve itici güçler, yoksunluk ve dışsal etkiler, yönelim süreci, organize edilen değişim ve davranışsal niyetlerdir. İkna konusunun yapı taşları ise bireyi harekete geçirmek için motive etmek, bilinçli bir niyet ya da girişim, bireyin hareketinin yönünü tayin etme ya da manipülasyon, davranışı biçimlendirme, değiştirme ya da etkileme ve tüm bunları başarabilecek mesajları iletebilmektir. Motivasyon iknanın bir sürecini oluşturur ve bu nedenle ikna motivasyondan daha geniş bir alanı kapsarken, motivasyon iknanın tam merkezinde yer alır (Anık, 2000: 237-238). Siyasiler, tüm bu bahsedilen detaylarla oluşturulan mesajlarını seçmenlere iletirken sıklıkla 'ben de sizden biriyim', 'ben sizin için varım' gibi söylemlerle ortak bir payda ve duygusal bir bağ kurmaya gayret ederken, seçmenlerin birbirinden ayrilan özelliklerine uygun biçimde hareket etmeye özen gösterirler. Politik aktörlerin ikna faaliyetlerini gerçekleştirirken kimi seçmenleri evlerinde ziyaret etmesi, kimilerine televizyon gibi kitle iletişim araçları üzerinden seslenmesi, genç seçmenlere ise çoğu kez internet destekli bilgi iletişimi teknolojisi cihazları aracılığıyla ulaşması bu yüzdendir. Ayrıca seçmenlerin niteliklerine ve eğilimlerine göre hareket edilmesi sayesinde mümkün olan en fazla sayıda seçmene ulaşılabilmesi, daha fazla sayıda seçmenin ikna edilmesi olasılığını artırmaktadır. $\mathrm{Bu}$ aşamanın detayları planlama aşamasında belirlenir ve doğru zamanda uygulamaya geçilir. Siyasal ikna faaliyetleri gerçekleştirilirken dikkat edilmesi gereken bir diğer unsur ise gönderilen mesajların alıcı konumundaki seçmen kitlelerinde önceden planlandığ 1 gibi bir düşünce ve tutum değişikliği yaratıp yaratmadığının sürekli olarak kontrol edilmesine ve eğer ihtiyaç duyuluyorsa iknaya yönelik gerekli düzeltmelerin gecikmeden hayata geçirilmesine ilişkindir. Bir bakıma geri bildirim sürecidir. Bu aşamaya kadar yapılan faaliyetlerin seçmen kitlelerinde beklenen etki ve değişimi yaratıp yaratmadığının takip edilmemesi, etkilenme sürecinin kısa sürmesine ya da başarısızlıkla sonuçlanmasına yol açabilmektedir. Ancak politikacıların seçmenlere yönelik takibi çoğu kez geri bildirimin alınmasını sağlayacak yeni mesajların ve enformasyonların gönderilmesi şeklinde gerçekleşmelidir. Özellikle kitle iletişim teknolojilerindeki gelişmeler, bilginin hızla dolaşımını olanaklı hale getirmiş ve bu durum mesajı gönderen olarak politikacıların her an ve her türlü içerikle seçmenlere ulaşabilmesini mümkün kılarken, seçmen kitlelerinin ise siyasi mesajların yanı sıra çok fazla uyaran ile karşı karşıya kalmasına neden olmuştur. Kitle iletişim teknolojilerinin seçmenlere bu kadar kolay ve yoğun ulaşılabilmesini olanaklı hale getirmesi, politikacılar açısından her zaman avantaj yaratan bir etken olarak değerlendirilmemelidir. Kişinin kültürüne ve karakterine ait anlamlandırma pratiklerine ait kodlarla doğallaştırılarak oluşturulan mesajlar ve semboller 
tüketicilerin göndericilere karşı tüm dirençlerini kırıp, zaten maruz kaldıkları birçok mesajla bulanıklaşmış olan algıları gibi, muhakeme yeteneklerini de olumsuz etkileyebilmektedir. Bunun sonucunda ise seçmenlerin duygu, düşünce, eğilim ve tutumları oldukça hızlı değişebilmekte, yaratılmak istenen etki daha zor oluşturulabilmekte ya da yaratılan etki çok çabuk çözülebilmektedir. Bu durum ikna faaliyetlerinde parti ve siyasi aktörlerin, seçmenlere yönelik politik mesajlarını daha etkili olacak biçimde oluşturmalarını ve bunu sürekli olarak yinelemelerini zorunlu hale getirmektedir. Netice itibariyle dijital teknolojinin hiçbir ayrıcalık gözetmeksizin ileti paylaşımını herkes için anlık ve kolay hale getirmesi, ikna çalışmaları sürecinde tüm siyasi parti ve aktörlerin ikna faaliyetleri içerisinde hangi yönelimleri gerçekleştirdiğinin ve bu yönelimlerin seçmenler üzerinde yarattığı etki derecesinin ne olduğunun takibini de kaçınılmaz kılmaktadır.

İletişim teknolojilerindeki gelişmeler siyasal iletişim ve iknaya yeni bir boyut kazandırmakta, politik parti ve aktörler her yeni teknolojik gelişmeyle kendi politik yönelimlerini seçmenlere benimsetme ve onları bu doğrultuda ikna etme yolunda yeni olanaklar elde etmektedir. Seçim dönemlerinde siyasal partiler ve aktörler ideolojileri, vaatleri, parti teşkilatlanmaları gibi pek çok konuda seçmenleri bilgilendirme eğilimi gösterirken, aynı zamanda en fazla sayıda seçmenin oy verme davranışı üzerindeki kararsızlıklarını kendi lehine çevirebilmek adına her zaman en doğru iletişim kanalının arayışı içinde olmaktadır. "Büyük kitleleri yönetmeye talip olan siyasiler, bu amaçlarına ulaşabilmek için dönemin ihtiyaçlarına cevap verebilecek politikalar üretmek ve buna uygun söylemler geliştirmek durumundadırlar" (İnce, 2019:193). Seçmenlere doğru zamanda doğru kültürel kodlarla oluşturulmuş mesajlarla ulaşmak kadar, heterojen yapıda olan en fazla sayıda seçmene en doğru ve hızlı kanallarla ulaşabilmek de etkileşimin meydana gelebilmesi ve dolayısıyla siyasal iletişimin başarısı için önemlidir. Her gün büyük bir hızla gelişme gösteren dijital teknoloji politik kesim ile seçmenler arasındaki etkileşim potansiyelini daha da ileri taşırken, politik aktörler açısından da yeni kolaylıklar ve olanaklar sunmaya devam etmektedir. Örneğin; bir zamanlar yönetenlerin özel günlerdeki törenlerde halka görünmesiyle yüz yüze ve sınırlı imkanlarla yürütülen siyasal iletişim ve ikna çalışmaları artık her an ve daha geniş mekanlarda gerçekleşebilmeye başlamıştır. $\mathrm{Bu}$ nedenle çok daha fazla sayıda seçmene ulaşılabilmeye başlanmış, siyasal iknanın başarı potansiyeli ise eskiye nazaran oldukça artış göstermiştir. Özetle; her yeni teknolojik gelişmenin, siyasal iletişim ve iknaya yeni bir yön ve alternatif kazandırarak hem siyasal faaliyetleri hem de siyasal katılımı yoğunlaştırdığı söylenebilmektedir. Bugün gelinen son noktada internet alt yapısı üzerinden faaliyet gösteren bu çevrimiçi mecra, sunduğu olanaklar sebebiyle iletişim ve ikna çalışmalarında parti ve aktörler için vazgeçilemez bir ortam olarak nitelendirilmektedir.

İlk olarak 1996 yılındaki Amerika Başkanlık seçimlerinde seçim kampanya çalışmalarıyla siyasal yaşamda rol oynamaya başlayan internet, 2000'li yıllardan itibaren ise tüm demokratik sistemlerde temel siyasal iletişim aracı olarak işlev görmeye başlamıştır. "Artık adaylar ve partiler kendi sempatizanları ve seçmenleriyle hiçbir aracıya gerek kalmadan doğrudan doğruya iletişim kurabilmekte, gündemdeki konular hakkındaki görüşlerini onlarla aracısız olarak paylaşabilmektedir" (Akgün, 2008: 178). Yeni medya ve internet yalnızca politik aktörler için değil, seçmenler açısından da etkileşim kurabilmek adına vazgeçilmez bir ortam halini almıştır. Halkın politikacılara hiçbir aracıya gerek olmadan doğrudan doğruya ulaşabilmesini mümkün hale getiren yeni medya ve internet, bu yönüyle seçmen kitleleri için etkin bir siyasal katılımın yolunu açarken, katılımcı bir demokrasi açısından da gelecek vaat etmektedir. Bunun yanı sıra "internet aynı zamanda, partilerin ve adayların kendilerini hareketli görüntülerle, sesli olarak sunabileceği gibi konu-proje önerilerini, vaatlerini, programlarını kapsamlı bir şekilde üstelik etkileşimli olarak işleyebilmesine imkân tanımaktadır" (Aktaş, 2004: 216).

Sınırsızlık özelliği sayesinde geleneksel siyasal iletişim çalışmalarının kapasite sorununu ortadan kaldıran yeni medya teknolojisi, zaman ve mekân sınırlarını da ortadan kaldırmasıyla birlikte parti ve adayların çok daha zengin içeriklerle ve çok daha fazla seçmene aynı anda ve canlı olarak ulaşabilmesine imkân tanımaktadır. Bu yüzden internet, demokrasiyle yönetilen ülkelerde 
siyasal iletişim, ikna ve kampanya çalışmaları sürecinde hızla kabul görmüş ve geleneksel iletişim araçlarının yerini almaya başlamıştır. Günümüzde çoğu parti ve adaylar seçim kampanya bütçelerinin önemli bir kısmını yeni medya platformuna ayırmaktadır. Çünkü yeni medya ve sosyal ağlar birbirinden farklı sosyo-demografik özelliklere sahip çok sayıda seçmenin aktif şekilde yer aldığı ve siyasal toplumsallaşması için ihtiyaç duyduğu politik bilgilerin çoğunu buradan edinmeyi tercih ettiği bir ortamdır. "We are Social'ın verilerine göre bugün dünyada yaklaşı üç milyar aktif sosyal medya kullanıcısı bulunmaktadır" (Sine ve Sarı, 2018: 369). Türkiye'de ise her geçen gün hızla artan kullanıcı sayısıyla büyüme gösteren internete erişim, 2018 yılı verilerine göre her 10 hane halkından sekizini kapsayacak noktaya ulaşmıştır. Türkiye İstatistik Kurumu'nun verilerine göre, 2017 yılında \%66,8 olan internet kullanımının 2018 yılında \%72,9'a ulaşması (Türkiye İstatistik Kurumu; www.tuik.gov.tr, e.t 02.06.2019) internet kullanımının her geçen y1l oldukça ciddi bir ivmeyle büyümeye devam ettiğine ve bilgi edinme ve iletişim kurmada geleneksel yöntem ve araçların kullanımına oldukça önemli bir alternatif haline geldiğine işaret etmesi bakımından önem arz etmektedir. Tüm bu verilerin de gösterdiği üzere yoğun bir kullanım potansiyeli bulunan bu online platform, kamuoyu oluşumunda önemli unsurlar haline gelmiş ve bu nedenle gündem belirleme konusunda vatandaşlar pasif konumdan çıkarak aktif rol oynamaya başlamışlardır. İhtiyaç duyduğu bilgileri geleneksel araçlar yerine yeni medyadan öğrenmeyi tercih eden kişi sayısının hızla artış göstermesine bağlı olarak ise artık siyasal parti ve aktörlerin de seçmenlerle etkileşimde yeni medya ve interneti neredeyse birincil siyasal iletişim ve ikna kanalı olarak kullanmaya başladığı söylenebilmektedir. Ayrıca yeni medya ve internet sayesinde politikacıların hem seçmen kitlelerine daha yakın olabilmesi, hem de seçmenin nabzını an be an tutabilmeleri mümkün hale gelmektedir. Bununla beraber reklamların etkileme ve ikna gücüne karşı her zaman bir önyargı ile yaklaşan seçmenlerle sosyal medya aracılığ ile çok daha samimi ve içten bir iletişim kurulabilmektedir. McNair'e göre, reklam siyasal iletişimde hedef kitlelere iletilmek istenen mesajların genellikle önyargıl1, taraflı ve ayrıca propaganda olarak algılanmasından dolayı önemli bir zayıflığa sahip olduğundan iknada siyasal reklamın etkinliği her zaman sinırlıdır. Bu nedenle, arzu edilen mesajların seçmenlere iletilmesinde reklama nazaran diğer iletişim tarzları daha etkilidir (McNair, 2003: 130). Yeni medya ve internet, siyasilere aynı zamanda değişen kamuoyu gündemini daha hızlı takip edebilme ve hatta önemli paylaşımlar aracıllğıyla gündemi belirleme olanağı da sunmaktadır. Bu durum, yönetim gücüne erişmek isteyen parti ve siyasi aktörlerin daha etkileyici politik mesajlar hazırlayabilmesinde önemli bir avantaj teşkil etmektedir.

Yeni medya ortamı ve sosyal ağlar, bireylerin gerçek kimlikleriyle var olmasını zorunlu kılmayan yapısı sayesinde, seçmenlerin gerçek sosyal ortamlardan farklı olarak görüşlerini bu sanal ortamlarda daha kolay açığa çıkarmasını sağlarken, siyasal tartışmalara daha etkin katılması sayesinde ise seçmenin politik konularda kamuoyuna yön verme potansiyelini artırmaktadır. Sanal sosyal ağlarda şeffaf bir duruş ortaya koyma girişkenliği gösteren seçmenler, bununla beraber sosyal medyadaki takipçi sayılarına ve etkinliklerine bağlı olarak siyasilere yönelik diğer seçmen algılarını ve eğilimlerini de etkileyebilmekte, yeni kamusal tartışmalar meydana getirebilmekte, destekleyici ya da karşıt eylemlere öncü olabilmektedirler. Bu özellikleriyle yeni medya ve sosyal ağlar, politikacıların seçmenin nabzını tutmaya yönelik ihtiyaç duyduğu bilgileri sağlamakla beraber hipermetinsellik ve hiperlink özellikleri sayesinde ise seçmenlere oy verme davranışını belirleyebilmesinde ihtiyaç duyduğu daha kapsamlı politik bilgilere farklı kaynaklardan erişebilmesi olanağı da tanımaktadır. Bunun anlamı şudur ki, seçmenler yeni medya sayesinde koşullandırılmış bir kamuoyu etkisini ve siyasal iletişimde politikacılardan seçmenlere doğru uzanan tek yönlü veri akışını sona erdirmiş ve bu bağlamda yönetim gücünü elde etmek ya da devamlılığını sağlamak isteyen parti ve aktörlerin yönlendirme, güdümleme ve ikna etmedeki etkinliğinin karşısına diğer bilgi kaynaklarını yerleştirmiştir. Netice itibariyle sosyal ağlar ve internet, seçmenleri geleneksel dönemden farklı olarak parti ve politik figürlerin gündemini bile etkileyip yönlendirebilecek kadar aktifleştirmiş ve etkin bir siyasal katılımın önünü açmıştır. İnsanlar, interneti daha çok aktüel bilgilere erişmek, karşıllklı bilgi paylaşmak ve içeriklere yorum 
yapmak için kullanmaktadır. Buna bağlı olarak da internet siyasete ilgiyi arttırmakta, kişiler arasında siyasi liderlerin mesajlarına tepki vermeye, protesto gösterilerinin örgütlenmesine, düzenlenmesine, ortaklaşa fikirlerin paylaşılması ve eylemlerin duyurulmasına ve yayılmasına firsat sunmaktadır (Göksu, 2016: 61).

Sanal ortamda sosyal ağların seçmenleri siyasal iletişim açısından bu denli etkinleştirmesi, olumlu yaklaşıma göre katılımcı bir demokrasinin yolunu açmaktadır. Ancak seçmenlerin sanal sosyal ağlarda bu denli kolay ve yoğun paylaşımlarda bulunması, eleştirel bağlamda bu ortamın siyasilerin ikna ve pazarlama faaliyetlerinde ihtiyaç duyduğu verileri anlık ve kapsamlı olarak sunmasına ve buna bağlı olarak siyasilere daha fazla avantaj sağlayan bir ortam olduğu tartışmasına yol açmaktadır. Bir sosyal ağ sitesi olarak Facebook günümüzde gerek partiler gerek politik aktörler gerekse de parti ve aktörlerin takipçisi durumunda olan seçmenler tarafından siyasal iletişim, tanıtım, pazarlama ve ikna faaliyetlerinde yoğun olarak kullanılmaktadır. "Facebook'un sosyal medyada yürütülen seçim kampanyalarında bir fenomen olarak ortaya çıkması 2008 Amerikan Başkanlık seçimleriyle olmuştur" (Aktan, 2017: 92). Amerika Birleşik Devletleri 2006 ara seçimleri incelendiğinde, adayların Facebook profillerini nasıl kullandıkları ve bunun onların oylarına etkisi üzerinde durulmuş; adayların Facebook sayfalarından sağladığı desteğin seçim sonucunu önemli bir şekilde etkilediği görülmüştür. Çalışmada en önemli bulgulardan biri ise adaylardaki coşkunun ve desteğin yoğunluğunun, Facebook takipçi sayıları ile orantılı olduğudur (Williams ve Gulati, akt. Eser ve Güler, 2015: 203). Aradan geçen zaman içerisinde internet altyapısı üzerinde çalışan yeni medya ortamlarının kendi içinde büyüme potansiyelini hız kesmeden sürdürmesine ve sosyal ağ çeşitliliğinin artmasına karşın, Facebook siyasal iletişim ve ikna faaliyetlerinin en önemli mecralarından biri olarak yerini korumaya devam etmiş̧tir. Siyasal iletişim eyleminde ikna potansiyelinin arttırılabilmesi için seçmenleri etkileşimde bulunmaya, yani fikirlerini beyan etmeye teşvik edecek ortamlara ihtiyaç vardır. $\mathrm{Bu}$ anlamda Facebook, katılımcılığı, çoğulculuğu ve azınlıkların da seslerini duyurabilmesini sağlaması yanında her konuda fikirlerin özgürce tartışılması esasına dayanan kamusal alanın sanal ortama taşınmasına da katk1 sağlayarak bir e-kamusal alan olma görevini de üstlenmektedir. Özellikle seçim öncesi dönemde rakip parti ve aktörlerin hız verdiği siyasal iletişim ve ikna faaliyetlerine Facebook'un en önemli katkıları; çok fazla sayıda seçmene aynı anda ulaşılabilmesinin sağlanması, ikna ve pazarlama faaliyetlerinin ucuza mal edilebilmesi, paylaşımlara seçmenlerin katılabilmesi ve yorum yapabilmesi sayesinde seçmenlerdeki düşünce, davranış ve tutum değişikliklerinin kolayca takip edilebilmesi, Facebook kullanıcısı seçmenlerin kendi duvarlarındaki paylaşımları yoluyla birbirlerini etkileyebilmesi ve daha fazla seçmenin siyasal sürece katılmasının yolunu açması olarak sıralanabilmektedir. Bu sıralanan olanaklar yanında parti ve adaylar tarafindan Facebook'un siyasal iletişim ve ikna aracı olarak yoğun talep görmesindeki en önemli sebeplerden biri de şüphesiz ki, bu sosyal ağ sitesinin vatandaşlar arasında yaygın bir kullanım potansiyeline sahip olmasıdır. "Türkiye İstatistik Kurumu 2015 verilerine göre Türkiye nüfusunun \%61'nin, yani 40 milyonun Facebook kullanıcısı olduğu yapılan araştırmalarda ortaya çıkmaktadır" (Tunca, 2015, akt. Yetişkin, 2016: 24). PRNet'e göre ise, 2018 yılının Ekim ayı itibariyle Türkiye'de 43 milyon Facebook, 37 milyon Instagram, dokuzar milyon da Twitter ve Snapchat kullanicisı bulunmakta. Türkiye, Facebook kullanıcı sayısında dünya genelinde dokuzuncu sırada bulunmaktadır (milliyet.com.tr, 2019). Rakamlar, Facebook kullanımının Türkiye'de ne kadar yaygın olduğunu ve sürekli bir artış trendi içerisinde olduğunu göstermesi açısından dikkat çekicidir.

Siyasal parti ve adaylar, ikna ve iletişim faaliyetleri boyunca seçmende yaratmak istedikleri etki ve değişimi gerçekleştirebilmek adına Facebook'tan partiler ve adaylar adına hesaplar açmak, bu hesaplardan bilgilendirici ve seçmenleriyle etkileşim sağlama amaçlı paylaşımlar yapmak ve online reklamlar vermek yoluyla yararlanmaktadır. Ayrıca seçmenler tarafindan da Facebook'ta partiler ve adaylar adına açılan birçok hesaba rastlamak mümkündür. Sosyal etkileşimle oluşan tartışma demokrasinin ruhu olması nedeniyle (Kim vd. 1999, 362. Akt. Bernstein, 2003: 218), siyasetçilerin seçmen kitlelerine gönderdikleri mesajların çok hızlı ve kolay bir şekilde geri 
bildirimini almalarına olanak tanıyan Facebook, aynı zamanda siyasilerin gerçekleştirdikleri etkinlikleri de canlı olarak bu ortam üzerinden seçmenleriyle paylaşabilme ve bu sayede onlarla anlık olarak etkileşime geçebilme ve onların fikirlerini özgürce birbirleriyle paylaşabilme ve tartışabilme imkânı tanıması ile de adeta bir sanal kamusal alan olarak işlev görmektedir. Facebook, seçmenlerin politik sürece dahil olmalarını da mümkün kılmasıyla siyasilere, seçmenleri ve hedef kitleleriyle sürekli olarak iletişimde olarak onları kendilerine daha fazla bağlama ve hatta destekçi sayılarını büyütme firsatı sunmaktadır. Bilgi iletişimi teknolojisinin akıllı cihazlarıyla internet üzerinden kullanıcıların paylaşmak ve sosyalleşmek için yararlandığı teknoloji ve yapay zekanın öğrenen makineler destekli sosyal medya uygulamaları, kullanıcıların hayat tarzlarını, alışkanlıklarını ve davranışlarını içeren kültürünü bu uygulamaların sağlayıcıları tarafindan öğrenilmesini sağlamakta ve bunun sonucu adeta kișiye özel hazırlanan, ki buna 'Kișiselleștirilmiș sanal iletişim' diyebiliriz, çok sayıda ikna edici mesaja maruz kalan kullanıcılar, çoğu zaman farkında olmadan istenilen yönde davranış değişikliğine teşvik edilmektedir. 'Kişiselleştirilmiş sanal iletişim', büyük verinin sanal ortamdan elde edilerek psikografik veri analizi yöntemleri ile bireylerin kişilik ve davranış kültürünün tanınması sonucu kullanıcıların adeta kendileri tarafından oluşturulan mesaj içerikleriyle mümkün olabilmektedir. Sanal ortamlardan elde edilen bilgilere dayanılarak kendi paylaşımları ve sevdikleri içeriklerle oluşturulan mesajlar, kullanıcılarda 'işte tam da istediğim ürün/hizmet bu' hissi uyandırmakta ve istediklerini bulduklarını düşündürerek, onların doğru olmayan kararlar vermelerine neden olmaktadır.

Sosyal medya hesapları, arama motorları, web sayfalarında gezinme, ilgili sayfalarda harcanan zaman ve tıklama sayıları gibi kullanıcıların internet ortamlarında bıraktığı izler, bu ortamların sağlayıcıları tarafından kullanııların alışkanlıklarını ve dolayısıyla kültürlerini öğrenmek adına, çoğunlukla kullanım sırasında önceden izin alınarak toplanıp, analiz yöntemleriyle anlamlandırılarak reklam verenlere veya bu tarz verilere ihtiyacı olan kuruluşlara satılmaktadır. Söz konusu sanal ortamdan elde edilen verilerle kullanıcıların kişilik özellikleri ve davranış kültürlerine yönelik olarak neler yapılabileceği ile ilgili en çarpıcı örneklerden birisi, kamuoyunu uzun süre meşgul eden Facebook'un elinde bulundurduğu kullanıcı verilerini tam da kullanıcıların hesap açarken kabul ettiği şekilde, ürün ve hizmet geliştirmek amacıyla üçüncü şahıslarla veya şirketlerle paylaşmasıdır. Facebook'un, özellikle Cambridge Analytica firması ile paylaştığı iddia edilen kullanıcı verilerinin ilgili firma tarafindan seçimlerde kişilerin davranışları üzerinden kültürlerini öğrenmek ve hatta yine onların davranışlarını ve kültürlerini istedikleri yönde değiştirmek amacıyla oluşturulan mesajlarda kullanılması, kişisel verilerin ve bunlarla oluşan büyük verinin önemini, onunla neler yapılabileceğinin şaşırtıcı örnekleriyle bir kez daha ortaya koymuştur. Cambridge Analytica tarafından Facebook kullanıcıların verilerine dayanılarak gerçekleştirilen ve hala etik olup olmadığı ve kullanıcılar tarafindan verilen izinlere dayanarak yapılıp yapılmadığı konusundaki tartışma ve hukuki davaların devam ettiği çalışmada, çalışmayı gerçekleştiren Cambridge Analytica'nın eski CEO'su Alexandre Nix'e göre, bireylerin kişilik, tutum ve davranışları özellikle sosyal medya ortamlarından elde edilen verilerin çeşitli algoritmalarla detaylı bir şekilde analizi sonucunda öğrenilerek bir oda içerisinde, aynı ortamda bulunan farklı kişilik özelliklerine sahip eşlere bile aynı konuda birbirinden farklı mesajlar gönderilebilmektedir (Concordia, 2016). Kullanıcı davranışları ve alışkanlıkları üzerinden psikografik analizler aracılığıyla kişiler bazında davranışlara ait kültür haritasını çizip, kullanıcılara/hedef kitlelere kişiliklerine ve kültürlerine daha uygun etkili sembollerle oluşturulmuş mesajlar göndererek onları istenilen davranışa veya tüketime güdülemek, bilgi toplumu çağında bilginin en önemli değer olduğunu ortaya koyması açısından dikkat çekicidir. Sembollerin yaşantımızda çok önemli bir yeri olup, düşüncelerimizde ve davranışlarımızın oluşumunda çok önemli rolleri vardır (Berger, 2000: 38). Elektronik ve mobil ortamlarda çevrimiçi iken gerçekleştirdiğimiz tüketim ve kendi davranış kültürümüze ait örüntülerimizden oluşan sanal izlerin analizleri ile gerçekleştirilip, elektronik ve mobil araçlar üzerinden maruz bırakıldığımız, tüketimi teşvik edici uyaranlara çoğunlukla direnebilmemiz mümkün olamamaktadır. 
Mobil akıllı cihazların internet ve sosyal ağları her an kullanılabilir hale getirmesi, sanal ortamı hem bilgi edinimi hem de bilgi yayımında çok sayıda birey tarafından öncelikli olarak tercih edilen bir kanala dönüştürmüştür. Sosyal medyanın her geçen gün kullanıcı sayısını arttırması ve bireylerin bilgi ediniminde dijital ortamı bu denli tercih etmesi ise politik aktörler için siyasal iletişim ve ikna çalışmalarında bu mecrayı vazgeçilemez kılmıştır. Araştırmada, dünyada siyasal iletişimde yaygın kullanımı nedeniyle bu alanda sosyal medya araçlarının en önemlilerinden birisi haline gelen Facebook'un Cumhur ve Millet ittifakı adaylarının 23 Haziran 2019 İstanbul yerel seçimlerinde siyasal iletişim kampanyaları için hedef kitlelerle ve/veya seçmenlerle bu araç üzerinden etkileşime geçme başarıları analiz edilerek ortaya konmaya çalışılacaktır. Facebook'un sosyal bilim araştırmaları için önemli avantajları olup, bu avantajlar şu şekilde sıralanabilir: Oldukça büyük olan kullanıcı kitlesi nedeniyle büyük potansiyel katılımcı sayısı havuzu, açık sosyal doğası içerik paylaşımını teşvik eder ki bu nedenle araştırmacılar kullanıcıların demografik, ilgi alanları ve sosyal ağ gibi profil verilerine ulaşabilirler. Facebook, her geçen gün daha fazla sosyal etkileşime aracı olduğundan Facebook'tan araştırmacılar için detaylı veri elde etmek, sosyal ve kişisel davranışları yakından analiz etmek de oldukça kolaylaşmaktadır (Rife vd., 2014: 2). Facebook kullanıcıları ünlü kişiler, politikacılar, kitaplar ve markalar gibi konularda Facebook sayfaları, gönderiler, fotoğraflar gibi çeşitli içerikleri kendi ilgilerini belirtmek için beğenirler ve bundan dolayı söz konusu beğenileri diğer reklam ortamlarının dijital ayak izleri gibi kabul edilebilir (Matz vd., 2017: 12715). Bu nedenlerden dolayı bu araştırmada bir siyasal iletişim aracı olarak Facebook üzerinden yapılan paylaşımlar ve sonuçları analiz edilecektir. Araştırmada cevabı aranacak sorular şöyledir;

- Q1: Facebook'ta sahip olunan takipçi sayısı erişim ve etkileşim başarısına aynı oranda yansimakta midir?

- Q2: Aristo'nun Ethos, Pathos ve Logos unsurlarından oluşan ikna kuramı siyasal iletişimde etkin olarak kullanılmakta midır?

Araştırma sorularının sınanması için 23 Haziran 2019 İstanbul yerel seçimleri Facebook mecras1 özelinde incelenecektir. Türkiye'deki son seçim olan 23 Haziran 2019 İstanbul yerel seçimine katılan partiler tarafindan bu seçime atfedilen önem nedeniyle bu seçimin adeta bir genel seçim havasına bürünmesi, araştırmanın konusu olarak bu seçimin tercih edilmesinin en önemli nedenidir. Bunun en önemli göstergelerinden birisi, 17 yıl aradan sonra iki ittifakın adayının televizyonda bir araya gelerek seçmenlerin karşısına çıkıp projelerini sunarak onları ikna etme çabaları olmuştur. Bu nedenle araştırmada Türkiye'nin önde gelen siyasi partilerinden Adalet ve Kalkınma Partisi ve Milliyetçi Hareket Partisi'nin oluşturduğu Cumhur ittifakı adayı Binali Yıldırım ve Cumhuriyet Halk Partisi ve İyi Parti'nin oluşturduğu Millet ittifakının adayı Ekrem İmamoğlu'nun 23 Haziran 2019 İstanbul yerel seçimine yönelik Facebook kampanyalarındaki paylaşımları analiz edilecek ve adayların bir siyasal iletişim aracı olarak Facebook üzerinden seçmenlerle kurmaya çalıştıkları ikna odaklı etkileşim ve sonuçları değerlendirilecektir.

\section{Metodoloji}

Facebook, etkileşimi anlamak için sosyal medya etkileşim araştırmalarında en çok analiz edilen platform olup, Popülerlik Etkileşimi, beğeni sayıları, yorum sayıları, takipçi sayıları, duvar yazısı uzunluğundan oluşan metriklerin ölçülmesi ile gerçekleştirilir (Rapp vd. 2013, akt. Perrealut ve Mosconi, 2018: 3573). Bu araştırmada Popülerlik Etkileşimi yaklaşımında belirtilen duvar yazısı uzunluğunun yerine paylaşım sayısı metriği analize dahil edilmiştir. Facebook'un Averaj Gönderi Etkileşim Oranı (FAGEO) olarak adlandırılan bu yaklaşıma göre (Average Post Engagement Rate), analiz edilen süre içerinde elde edilen paylaşım, beğeni ve yorum sayısının toplamının gönderi sayısına ve takipçi sayısına bölünmesi gerekir. Elde edilecek rakamın 1-2\% seviyelerinde olması başarılı olarak kabul edilir (Örnek, 2016). 
23 Haziran 2019 İstanbul yerel seçimde ittifak adayları Facebook'ta seçim kampanyalarına yönelik paylaşımlarını ağırlıklı olarak kendi kişisel hesapları üzerinden yapmışlardır. Bu nedenle araştırmada Adalet ve Kalkınma Partisi ve Milliyetçi Hareket Partisi'nin oluşturduğu Cumhur ittifakı adayı Binali Yıldırım ve Cumhuriyet Halk Partisi ve İyi Parti'nin oluşturduğu Millet ittifakının adayı Ekrem İmamoğlu'nun 23 Haziran 2019 İstanbul yerel seçimine yönelik 16-23 Haziran 2019 tarihleri arasındaki sosyal medya araçlarından Facebook'taki kişisel hesaplarında yer alan siyasal iletişim kampanyalarına yönelik paylaşımlarının değerlendirilmesi amaçlanmaktadır. Araştırma, söz konusu iki ittifakın adaylarının paylaşımlarının Facebook kullanıcıları ve/veya seçmenler tarafından beğenilme gibi duygu durum bildirim sayıları, paylaşımlara yapılan yorum sayıları, Facebook'taki kişisel sayfalarının takipçi sayıları gibi metriklerin analiz edilip, toplam paylaşımları ile elde ettikleri etkileşim başarılarının FAGEO ile değerlendirilerek birbiri ile karşılaştırılması ile adayların söz konusu bu etkileşim sonuçlarını nasıl bir siyasal iletişim kampanyasına yönelik ikna stratejisiyle elde ettiklerini ortaya koyabilmek için adayların söz konusu zaman dilimi içerisinde yaptıkları ve en yüksek duygu durum paylaşımı yönünde etkileşim yaratan birer paylaşımının retorik analizi yöntemi ile çözümlemesine dayanmaktadır. Retorik analizi özellikle çözümlenecek içerikte ikna konusu önemli ise uygun bir çözümleme yöntemidir (Berger, 1998: 66).

\section{Araştırmanın Evreni}

Araştırmanın evrenini Adalet ve Kalkınma Partisi ve Milliyetçi Hareket Partisi'nin oluşturduğu Cumhur ittifakı adayı Binali Yıldırım ve Cumhuriyet Halk Partisi ve İyi Parti'nin oluşturduğu Millet ittifakının adayı Ekrem İmamoğlu'nun Facebook paylaşımları oluştururken, örneklemini ise FAGEO ölçümlemesi için ilgili adayların kendi Facebook sayfalarında 16-23 Haziran 2019 tarihleri arasında siyasal iletişim kampanyaları çerçevesinde yapmış oldukları tüm paylaşımlar ve Aristo'nun ikna kuramını içeren retorik analizi için ise yine aynı dönemde adayların en çok duygu durum paylaşımı yönünde etkileşim yaratan birer paylaşımı oluşturmaktadır. Adayların analiz edilecek paylaşımlarında özellikle duygu durum bildiriminin seçilmesi, Facebook üzerinden etkileşim yaratan diğer unsurlara göre kullanıcılar tarafından en çok tercih edilen olmasindandir.

\section{Sinırlılıklar}

Araştırma, Adalet ve Kalkınma Partisi ve Milliyetçi Hareket Partisi'nin oluşturduğu Cumhur ittifakı adayı Binali Yıldırım ve Cumhuriyet Halk Partisi ve İyi Parti'nin oluşturduğu Millet ittifakının adayı Ekrem İmamoğlu'nun 23 Haziran 2019 İstanbul yerel seçimine yönelik siyasal iletişim kampanyalarında sosyal medya araçlarından Facebook'ta kendi hesaplarındaki 1623 Haziran 2019 tarihleri arasında yapmış oldukları paylaşımların analiz edilmesi ile sınırlıdır.

\section{Bulgular}

Araştırma konusu olan İstanbul yerel seçimlerinde Adalet ve Kalkınma Partisi ve Milliyetçi Hareket Partisi'nin oluşturduğu Cumhur ittifakı adayı Binali Yıldırım'ın Facebook sayfasını 332.354 kişi takip etmekte olup, seçim kampanyası çerçevesinde 16-23 Haziran tarihleri arasında Facebook üzerinden toplamda 63 paylaşım yapmıştır. Bu paylaşımlardan 40'1 video, 10 tanesi yazılı metinli fotoğraf, beşi afiş, dördü canlı yayın ve dördü de sadece yazılı metinden oluşmaktadır.

Cumhuriyet Halk Partisi ve İyi Parti'nin oluşturduğu Millet ittifakının adayı Ekrem İmamoğlu'nun ise Facebook sayfasını 1.599.630 kişi takip etmekte olup, yine aynı zaman dilimi içerisinde toplamda 66 paylaşım yapmıştır. Bunlardan 22'si yazılı metinli fotoğraf, 21'i canlı yayın, 17'si video ve altı tanesi de afiştir.

Adayların Facebook sayfalarından siyasal iletişim kampanyaları çerçevesinde yapmış oldukları paylaşım stratejilerinde en fazla göze çarpan farklara bakıldı̆̆ında; Binali Yıldırım'ın 
ağılıklı olarak video paylaştığı, buna karşı Ekrem İmamoğlu'nun ise rakibine göre canlı yayın ve fotoğraf paylaşımlarına daha fazla ağırlık verdiği görülmektedir. Her iki adayında çağımızın gereği olarak Facebook'ta görsel paylaşımlara oldukça fazla önem verdikleri ve siyasal iletişim stratejilerini görsellerin paylaşımı üzerine oluşturdukları görülmektedir.

Tablolarda da görüleceği üzere ilk bakışta tüm metriklerde Millet İttifakı adayı Ekrem İmamoğlu, Cumhur İttifakı adayı Binali Yıldırım'dan daha fazla etkileşim sağlamış gözükmektedir. Adaylar arasındaki en fazla fark, adayların paylaşımlarına yapılan yorumlarda olmuştur. Yüzdesel fark bakımından yorumları sırasıyla beğeniler, kullanıcıların paylaşımları, video erişimi ve canlı yayın erişimi izlemektedir. Analiz edilen 16-23 Haziran 2019 tarihleri arasında yapılan paylaşımlarla elde edilen paylaşım, beğeni ve yorum sayının toplamının gönderi sayısına ve takipçi sayısına bölünmesi ile elde edilen, araştırmada esas alınan FAGEO değerlendirmesine göre ise, Binali Yıldırım'ın gönderileri (tablo 2.) Ekrem İmamoğlu'nun paylaşımlarına (3,2\%) göre daha fazla etkileşim oranına sahiptir (3,7\%). Etkileşim sağlamada Binali Yıldırım daha başarılı olmuş olmasına rağmen, Ekrem İmamoğlu Facebook'ta paylaşımlarıyla daha fazla kişiye erişim sağlamıştır. Bunun en önemli sebebi ise Ekrem İmamoğlu'nun seçimlerdeki rakibi Binali Yıldırım'dan yaklaşık beş kat daha fazla takipçiye sahip olması olarak gösterilebilir.

Tablo 1: Adayların Facebook sayfalarında yaptıkları toplam paylaşım sayıları

\begin{tabular}{|l|r|r|r|}
\hline $\begin{array}{c}\text { Paylaşılan } \\
\text { İçerik }\end{array}$ & \multicolumn{1}{|c|}{$\begin{array}{c}\text { Binali } \\
\text { Yıldırım }\end{array}$} & $\begin{array}{c}\text { Ekrem } \\
\text { Imamoğlu }\end{array}$ & \multicolumn{2}{c|}{ Fark } \\
\hline Fotoğraf & 10 & 22 & -12 \\
\hline Yazı & 4 & 0 & 4 \\
\hline Afiş & 5 & 6 & -1 \\
\hline Canlı Yayın & 4 & 21 & -17 \\
\hline Video & 40 & 17 & 23 \\
\hline Toplam & 63 & 66 & -3 \\
\hline
\end{tabular}

Tablo 2: Adayların Facebook’ta yaptıkları paylaşımların toplam etkileşim ve erişim sayıları

\begin{tabular}{|c|c|c|c|c|}
\hline Toplam & $\begin{array}{c}\text { Binali } \\
\text { Yıldırım }\end{array}$ & $\begin{array}{c}\text { Ekrem } \\
\text { Ímamoğlu }\end{array}$ & Fark & $\begin{array}{c}\text { Fark } \\
\%\end{array}$ \\
\hline $\begin{array}{l}\text { Takipçi } \\
\text { Sayıs1 }\end{array}$ & 332.354 & 1.599 .630 & -1.267 .276 & $-381 \%$ \\
\hline $\begin{array}{l}\text { Paylaşım } \\
\text { Sayısı }\end{array}$ & 63 & 66 & -3 & $-5 \%$ \\
\hline $\begin{array}{l}\text { Etkileşim } \\
\text { Sayıs }\end{array}$ & 776.835 & 3.396 .541 & $-773.438,459$ & $-263 \%$ \\
\hline Beğeni & 599.200 & 2.658 .800 & -2.059 .600 & $-344 \%$ \\
\hline Yorum & 85.561 & 478.304 & -392.743 & $-459 \%$ \\
\hline Paylaşım & 92.074 & 259.437 & -167.399 & $-182 \%$ \\
\hline $\begin{array}{l}\text { Etkileşim } \\
\text { Oranı }\end{array}$ & $3,7 \%$ & $3,2 \%$ & 0,5 & $16 \%$ \\
\hline $\begin{array}{l}\text { Canlı Yayın } \\
\text { İzlenme } \\
\text { (Erişim) }\end{array}$ & 2.148 .000 & 13.209 .000 & -11.061 .000 & $-515 \%$ \\
\hline $\begin{array}{l}\text { Video } \\
\text { İzlenme } \\
\text { (Erişim) }\end{array}$ & 12.381 .900 & 7.475 .000 & 4.906 .900 & $40 \%$ \\
\hline
\end{tabular}


Tablo 3: Adayların Facebook'ta yaptıkları paylaşım başına ortalama etkileşim ve erişim sayıları

\begin{tabular}{|l|r|r|r|r|}
\hline $\begin{array}{c}\text { Her } \\
\text { Gönderi } \\
\text { İ̧̧in } \\
\text { Ortalama }\end{array}$ & $\begin{array}{c}\text { Binali } \\
\text { Yıldırım }\end{array}$ & $\begin{array}{c}\text { Ekrem } \\
\text { İmamoğlu }\end{array}$ & Fark & $\begin{array}{c}\text { Fark } \\
\text { \% }\end{array}$ \\
\hline $\begin{array}{l}\text { Etkileşim } \\
\text { Sayısı }\end{array}$ & 12.330 & 51.463 & -39.133 & $-317 \%$ \\
\hline Beğeni & 9.511 & 40.285 & -30.774 & $-324 \%$ \\
\hline Yorum & 1.358 & 7.247 & -5.889 & $-434 \%$ \\
\hline Paylaşım & 1.461 & 3.931 & -2.470 & $-169 \%$ \\
\hline $\begin{array}{l}\text { Canlı Yayın } \\
\text { İzlenme } \\
\text { (Erişim) }\end{array}$ & 537.000 & 629.000 & -92.000 & $-17 \%$ \\
\hline $\begin{array}{l}\text { Video } \\
\text { İzlenme } \\
\text { (Erişim) }\end{array}$ & 309.548 & 439.706 & -130.158 & $-42 \%$ \\
\hline
\end{tabular}

\section{Binali Yıldırım'ın En Çok Beğeni Alan Gönderisinin Retorik Çözümlemesi}

İçerik, İstanbul Büyükşehir Belediye Başkan Adayı Binali Yıldırım'ın 23 Haziran seçimlerine yönelik gerçekleştirdiği seçim kampanyası kapsamında Facebook kanalı üzerinden yayınladığı seçim videosudur.

Paylaşım tarihi: 18 Haziran 2019 / Saat: 20:50

Duygu durum bildirim saylsı: 87.400

Video süresi: 1 dakika 33 saniye

Video içeriği: Binali Yıldırım'ın yıllardır içinde bulunduğu ve İstanbul Büyükşehir Belediye Başkan adayı olduğu Adalet ve Kalkınma Partisi'nin, geçen 25 yılda İstanbul'da verdiği hizmetler ve yaptığı yenilik ve düzenlemeler yer almaktadır.

Videoya ait duvar yazısı: "Yıllardır ülkem için aşmadık dağ, sermedik yol, atmadık köprü bırakmadım. Aldığım her görevi koltuk sevdasıyla değil, millet aşkı ve görev bilinciyle yerine getirdim. Şimdi gayem İstanbul, derdim İstanbul, hayalim İstanbul. Bu saatten sonra iş ehlinin, karar milletin." $\mathrm{Bu}$ başlıkta retoriğe ilişkin unsurlardan kafiye ve redif kullanılarak özellikle siyasetteki adanmışlık ve deneyime ve bu sayede elde edilen tecrübeye vurgu yapılmakta, söz konusu tüm bu birikimin şimdi İstanbul için kullanılacağı yönündeki kararlılık ortaya konmaktadır.

\section{Videoda Retorik Açısından Öne Çıkan Bölümler}

- Videoda hâkim tema, Adalet ve Kalkınma Partisi adayı Binali Yıldırım'ın partisiyle birlikte geçmiş 25 yılda İstanbul'a getirdikleri hizmetlerin, yumuşak bir fon müziği eşliğinde, bundan sonra kendisinin yapacaklarına kanıt olarak (Logos) gösterilmesine dayalı, bütünü anlatma stratejisi olan metonomi kullanılarak seçilmesi halinde bundan sonrasına yönelik güven yaratmaya çalışılmış, seçmenler bu yolla ikna edilmek istenmiştir.

- Giriş, gelişme ve sonuç bölümlerinden oluşan videonun giriş kısmı ilk 5 saniyelik bölümü kapsamaktadır. Bu kısımda Boğaz manzarası görüntüsüyle beraber İstanbul'u yönetmenin işin ehli olmak demek olduğu Binali Yıldırım tarafından ifade edilerek, gösterilen doğa güzellikleri görüntüleriyle İstanbul'un önemi hatıllatılmış ve söz konusu bu ilin yönetiminin kendisinin sahip olduğu tecrübe ile mümkün olabileceğine vurgu yapmıştır.

- Gelişme bölümünde İstanbul'da yol, yakıt, sanat, çevre, alt yap1 çalışmaları gibi birçok alanda yapılan hizmetler görseller eşliğinde Binali Yıldırım'ın ağzından aktarılırken, Binali 
Yıldırım bu örnekleri niçin kendisinin seçilmesi gerektiği sorusunun bir yanıtı olarak Logos'u gerçekleştiren ehil oluşunun kanıtları olarak sunmuştur.

- Seçilen sözcüklerin açık, anlaşı1ır ve kısa cümlelerin ağırlıkta olduğu videonun sonuç bölümü ise son 24 saniyelik bölümdür. Sonuç kısmında yer alan cümleler şu şekildedir: "25 yıl önce emin ellere teslim ettiğiniz bu büyük emaneti şimdi ehil ellerde daha da ileriye götürmeye talibim. İşi ehline verin, İstanbul kazansın! İşi ehline verin, Millet kazansın! İş ehlinin, karar Milletin.” Binali Yıldırım'ın ses tonunu diğer kısımlara göre yükselttiği bu bölümde, 25 sene önce verilen kararın doğruluğunu 'emin ellere teslim ettiğiniz' sözleri ile, kendisinin sahip olduğu tecrübeyi ise 'ehil eller' sözleri ile metonomi kullanıp uzmanlı̆̆ına vurgu yapıp, bu avantajını ortaya koyarak rakibine göre üstün olduğunu düşündüğü özelliğini ön plana çıkarmıştır. Konuşmasının "İşi ehline verin, İstanbul kazansın! İşi ehline verin, Millet kazansın!" bölümünde redif kullanımı yaparak sözlerinin seçmenlerin kulağına hoş gelmesini amaçlamıştır. "İ̧ ehlinin, karar Milletin" bölümünde ise retorik unsurlarından kafiye kullanımı söz konusudur. Ayrıca bu bölümde milletin kararının esas olacağına vurgu yapılarak millet, son sözü söyleyecek güce sahip olan karar mekanizması olarak ön plana çıkarılmıştır. Binali Yıldırım, 'kazanma' sözü ile metonomi kullanarak ifade ettiği zaferi ise, kendisinin seçilmesi durumunda İstanbul Şehri'nin ve bu şehirde yaşayan milletin elde edeceğine vurgu yapmıştır.

- Videonun genelinde güven, sadakat, hizmette kapsamll1ık ve rasyonalite unsurlarının ikna bileşenleri olarak kullanıldığı ve Ethos, yani kaynağın güvenilirliğine ağıllık verildiği söylenebilir. İsin ehline verilmesi vurgusu siyasal iletişim kampanyası mesajına kültürel kodlar aracığıyla anlam yüklenerek seçmenlerle Pathos yani duygusal bağ da inşa edilmeye çalışılmış ve yapılan hizmetlerden örnekler göz önüne serilerek Logos da gerçekleştirilmeye çalışılmıştır. Işsin ehline verilmesi video içerisinde 10 kez tekrarlanarak iknanın etkisi artırılmaya çalışılmıştır.

\section{Ekrem İmamoğlu’nun En Çok Beğeni Alan Gönderisinin Retorik Çözümlemesi}

23 Haziran 2019 İstanbul Yerel Seçiminde İstanbul Büyükşehir Belediye Başkan Aday1 Ekrem İmamoğlu'nun seçim kampanyası çerçevesinde Facebook kanalı üzerinden yayınladığı ve en çok etkileşim oranına sahip seçim videosu.

Paylaşım tarihi: 17 Haziran 2019 / Saat: 00:07

Duygu durum bildirim saylst: 169.000

Video süresi: 2 dakika 12 saniye

Video içeriği: Aday Ekrem İmamoğlu'nun seçim çalışmaları kapsamında üç farklı alanda gerçekleştirmiş olduğu mitinglerden alınan kesitlerden oluşmaktadır.

Videoya ait duvar yazısı: "Daha yeni başliyoruz. İsraftan beslenen bir avuç insan değil, adalete susamış 16 milyon İ́stanbullu kazanacak. Her şey çok güzel olacak.”

\section{Videoda Retorik Açısından Öne Çıkan Bölümler}

- Giriş, gelişme ve sonuç bölümleri şeklinde kurgulanmış olan videonun giriş kısmında Pathos yani duygusal çekicilik ritimsel olarak arka arkaya 4 kez tekrarlanan seçim sloganıyla sağlanmaya çalışılmıştır. Videonun başlangıcından sonuna kadar seçim sloganın sıklıkla ön plana çıkarıldığı dikkat çekmektedir. 'Her şey çok güzel olacak' sloganı, videoda kullanıldığı her yerde fon müziği eşliğinde ve ritmik şekilde olmak üzere toplamda 11 kez söylenmiştir.

- Videonun İmamoğlu'nun konuşmasıyla başlayan 15. saniyesi gelişme kısmına geçildiği bölümdür. Bu bölümde Ekrem İmamoğlu'nun konuşması şu sözcüklerden oluşmaktadır: "Yolumuz uzun, heyecanımız yüksek, gençliğimiz var. Biz adalete susamış, demokrasiye 
inancı tam Türk gençliğiyiz." Logos yani rasyonel çekicilik, duyulan heyecan ve genç olma vurguları üzerinden gerçekleştirilmeye çalışılmıştır. Ekrem İmamoğlu, İstanbul'un yönetiminin zorlu ve yorucu bir süreç olduğunu belirtip, kendisinin Binali Yıldırım'dan daha genç ve heyecanlı olmasını bir avantaj olarak ön plana çıkararak seçmenleri bu şekilde ikna etmeye çalışmıştır. Gençliğin yüksek enerjisine ve heyecanına vurgu yaparak hem genç seçmenleri demokrasiye sahip çıkmasından dolayı övüp cezbetmeye ve hem de ileri yaşlardaki seçmenlere yönelik olarak İstanbul'u yönetmek gibi zor bir görev için gerekli olan enerjiye vurgu yaparak tüm seçmenleri ikna etmeye yönelik bir eğilim sergilemiştir. Konuşmanın bu bölümünde ilgili sözleri söylerken İmamoğlu, kullandığı ses tonu ve kullandığı kelimelere yaptığı vurgularla Pathos'u yani duygusal çekiciliği yaratmaya çalışmıştır. Konuşmasının bu bölümünde ellerini herkesi kucaklarcasına açıp havaya kaldırıp sallayarak vücut dili ile de söylediklerini pekiştirmiştir. Cümlesinin son bölümü olan "Türk Gençliğiyiz" bölümünde ise, bir anda sözlerindeki vurgusunu artırarak ve sağ elini yumruk yaparak havada sallaması ile de hitap etmekte olduğu gençliğe heyecanını aktarmaya çalışmıştır.

- Konuşmasının devamı şu şekildedir: "Bizim meydanlarımızda sevgi var, biz ısrarla bu milletin kavga etmesini istemeyen, bu milletin kucaklaşmasını isteyen insanlar olarak ısrarla kucaklaşacağız ısrarla kucaklaşacağız.” Bu cümlede iknanın duygusal çekicilik ile, duygusal çekiciliğin ise dayanışma ve kucaklaşmanın, birlik ve beraberliğin olduğu bir gelecek vaat edilerek, bu stratejik unsurlar üzerinden başarılmaya çalışıldığı görülmektedir. Ekrem İmamoğlu bu sözleri söylerken vücut diliyle kararlılığını ve inancını belirtmek ve söylemini güçlendirmek için tüm cümle boyunca iki elini yumruk yaparak havada tutmaktadır. İmamoğlu'nun seçim kampanyasını genel olarak 'sevgi, kucaklaşma, umut olma ve demokrasi' temaları üzerine kurduğu görülmektedir.

- Ekrem İmamoğlu, "Sakın gülen yüzünüzü kaybetmeyin, sakın, sakın yüreğinizdeki umudu kaybetmeyin" cümlesi ile milletin sahip olduğu güler yüzlülüğe vurgu yaparak, umut ile gülümseme arasında bir ilişki kurmakta ve umutsuzluğun gülümsemeyi yok edeceğini belirtmeye çalışmıştır. Bu nedenle videonun 1.50. saniyesinden başlamak üzere 5 saniye boyunca kendisini işaret ederek, gitgide yükselen ses tonu ve vurgulamalarla $4 \mathrm{kez}$ "umut burada" diyerek kendisinin gelecek için 'umut' olduğunu işaret ederek, kendisinin gülümsemenin kaynağı olacağını ilişkisel olarak anlatmaya çalışmıştır. Bu sözleri sırasında kollarını açarak kalabalığı kucaklarken, bazen de ellerini yumruk yaparak bu hususlardaki kararlılığını ve inancını vücut diliyle de pekiştirmiştir.

- Videonun sonuç kısmı ise 1,56. saniyede başlamakta ve seçim sloganı olan, 'her şey çok güzel olacak' sloganının fon müziği eşliğinde ritmik olarak $4 \mathrm{kez}$ tekrarlanmasıyla bitmektedir.

- Genel olarak videodaki ses ve sözcüklerin dikkat çekiciliği ve bellekte kalıcılığı arttırmaya yönelik olarak hazırlandığı dikkat çekmektedir. Sesler ve sözcükler belli bir ritim ile verilirken, konuşma tümüyle açık, anlaşılır sözcükler ve kısa cümleler üzerine inşa edilerek seçmenler harekete geçirilmeye çalışılmıştır.

- Videodaki ses, görüntü ve aday İmamoğlu'na ait konuşma kesitlerinin genel olarak coşkuya ve duygusal çekiciliğe yönelik olduğu söylenebilir. İmamoğlu'nun beden dili ile konuşmasındaki vurgu ve tonlamaların bir uyum içinde ilerlediği, konuşmasını izleyiciye dönerek ve onlarla göz teması kurarak gerçekleştirdiği ve bu sırada gömleğinin kollarının dirseklerine kadar sıvalı olması ile de zorlu göreve başlamaya hazır olduğu izlenimi vermeye çalıştığı söylenebilir. Videoda genel olarak gençlik, adalet, birlik ve beraberlik temalarının işlendiği dikkat çekmektedir.

\section{Adayların Siyasal İletişim Stratejilerinde Dikkat Çeken Farklar}

- Her iki videonun da etkileşim oranları arasında büyük oran farklılıkları görünmektedir. Ekrem İmamoğlu'nun 2 dakika 12 saniyelik seçim videosu 169.000 duygu durum bildirimi 
ve 11.400 beğeni sayısına sahipken, Binali Yıldırım'ın 1 dakika 33 saniye süren videosu 87.400 duygu durum bildirimi ve 7.700 yorum almıştır.

- Ekrem İmamoğlu'na ait videoda genel olarak mantıksal ilişkiler ve somut örneklendirmeler gibi rasyonel çekicilik unsurlarından daha çok coşkuya dayalı ve Pathos adı verilen duygusal çekicilik unsurlarının bulunduğu dikkat çekmektedir. Binali Yıldırım'a ait videoda ise duygu ve coşkulara seslenmek yerine seçmenlerin rasyonel çekicilik unsurlarıyla ikna edilmeye çalışıldığı, bu bağlamda da sıklıkla verilen hizmetlere ilişkin somut örneklerin sunulduğu görülmektedir.

- Ekrem İmamoğlu, Ethos yani kaynağın güvenilirliğine ilişkin olarak sıklıkla 'gençliğimiz var' ve 'umut burada' gibi açık ifadeler ile kendini işaret ederken, Binali Yıldırım ise kaynağın güvenilirliğine ilişkin olarak verilen hizmetlerin örnek gösterilmesi yoluyla partiyle kendisini bütünleştirmektedir.

- Ekrem İmamoğlu'na ait videoda sözlerin belli bir ritim ile sunulması ve vücut dilinin etkin kullanımı gibi genel olarak dinamik ve akılda kalıcılı̆̆ı artırmaya yönelik unsurlar yer alırken, Binali Yıldırım'a ait videonun ise yapılanların hatırlatılmasına yönelik unsurları barındırdığ 1 söylenebilir.

- Ekrem İmamoğlu'nun kendi seçim kampanyasına ait videosunun tamamında göründüğü, beden dili, vurgu ve tonlamaları da yoğun biçimde kullandığı dikkati çekerken, Binali Yıldırım ise yalnızca videosunun sonuç kısmında görünmekte ve beden dili, tonlama ve vurgulamalarının stratejisini üzerine kurduğu uzmanlığın sakinliğini Ethos olarak yansıttığı söylenebilir.

- Ekrem İmamoğlu'nun videosunda seçmenlerin 'adalet, demokrasi, sevgi, birlik ve beraberlik' gibi unsurlar üzerinden, Binali Yıldırım'ın videosunda ise seçmenlerin kanıt göstererek gerçekçilik ve mantıksal olma unsurlanıla ikna edilmeye çalışıldığı görülmektedir.

- Her iki adaya ait videonun da giriş-gelişme ve sonuç bölümlerinden oluştuğu ancak bu bölümlerde yer alan unsurların ve ikna bileşenlerinin birbirinden tamamen farklı olduğu gözlemlenmektedir.

\section{Sonuc}

Hem siyasal iletişim eyleminin kaynağı ve mesajın yaratıcısı olarak politik aktörlerden gelen iletilerin, hem de siyasal etkileşimin göstergesi olarak seçmenler tarafindan siyasetçilerin yaptığı paylaşımlara yapılan geribildirimlerin incelendiği çalışmada en fazla etkileşim sağlayan içeriklerin ses ve görüntü içeren videolar, en az ise duvar yazıları olduğu anlaşılmıştır. Özellikle uzun duvar yazılarına ilişkin etkileşim oranlarının düşük olmasının nedeni, içinde bulunduğumuz bilgi toplumunda sosyal medyada genel yapısı gereği fotoğraf veya videodan oluşan görsel ağırlıklı paylaşımların yazıya oranla çok daha fazla ilgi görmesidir. Özellikle genç seçmenler tarafından daha yaygın olarak kullanılan sosyal medyada kolay anlaşılan ve çabuk tüketilebilen video gibi içerikler, okumak, üzerinde durup düşünmek ve yavaş tüketilen yazılı metinlere oranla çok daha fazla tercih edilmektedir. Bu durum, bu araştırmada yapılan inceleme sonucunda elde edilen verilere göre her iki adayın da Facebook paylaşımlarında uzun duvar yazılarından ziyade fotoğraf ve video gibi içeriklere daha fazla ağırlık vermelerinin sebebi olarak da gösterilebilir.

Çalışmada gerçekleştirilen FAGEO değerlendirmesine göre, Binali Yıldırım'ın Ekrem İmamoğlu'ndan daha az takipçisi olmasına karşın, etkileşim (interaction) oranında Ekrem İmamoğlu'na göre daha başarılı olduğu tespit edilmiştir. Buna karşın Ekrem İmamoğlu'nun erişimdeki (reach) başarısı Binali Yıldırım'dan fazla olmasının nedeni, Ekrem İmamoğlu'nun Facebook'ta daha fazla takipçi sayısına sahip olması olarak gösterilebilir. Ayrıca Facebook'un algoritması gereği bir paylaşımın erişim oranları ve etkileşim oranları sayısı yükseldikçe kullanıcıların haber akışlarında (news feed) diğer paylaşımlara göre daha öncelikli olarak yer almakta ve doğal olarak kullanıcılar tarafından daha fazla görülmesi sağlanmaktadır. Bu durumun 
daha fazla takipçisi olan adaya avantaj sağlayabileceği düşünülebilir, fakat Ekrem İmamoğlu, araştırmamıza konu olan bir hafta içerisinde rakibi Binali Yıldırım'dan paylaşımlarının ortalamasında sayıca fazla olan takipçileri nedeniyle daha fazla erişim sayısına ulaşmasına rağmen, takipçi sayısı üstünlüğünü erişim sayısına aynı oranda yansıtamamıştır.

Bu bulgular 1şığında, Facebook takipçi sayısındaki artışın, ilgili takipçilerin haber akışında mesaja maruz kalma oranındaki artışa etki ettiği ve bunun da erişim ve buna bağlı olarak da etkileşim potansiyelini yükselttiği ifade edilebilir. Bu tespitler, Facebook'ta takipçi sayısı ile erişim ve etkileşim oranının arasında doğru yönde bir ilişki olduğunu göstermesine karşın, takipçi sayısının artışıyla etkileşim oranının aynı oranda geliştiği anlamına gelmediğini ve onu garanti etmediğini de belirtmektedir. Bu yönde artış gerçekleștirebilmek, politikacıların takipçilerinin beklentileri doğrultusunda onların ilgililerini çekebilecek fotoğraf, video ve özellikle de canlı yayın gibi görsel içerikler paylaşmaları ile sağlanabilir. Ayrıca, araştırmada Facebook üyesi seçmenlerin canlı yayın paylaşımlarına video paylaşımlarından çok daha fazla ilgi gösterdiği belirlenmiştir. Bununla birlikte Binali Yıldırım'ın her bir canlı yayın paylaşımının kendisinin takipçi sayısının yaklaşık iki katı seçmene erişmesi, seçmen kitlesinin ilgili adayı takip etmese bile canlı yayınlara aşırı ilgili gösterdiğini ortaya koyması bakımından önemlidir. Her iki adayın da Aristo'nun ikna kuramı unsurlarını siyasal iletişimlerinde değişik tarzlarda kullandıkları görülmüştür.

Sonuç olarak, içinde bulunduğumuz bilgi çağında siyasetçiler açısından seçmenlere her zaman ve her yerde ulaşmak ve onları parti ideolojileri ve siyasal konularda bilgilendirmek ve ikna etmek internet ve sosyal medya ortamları aracılığıyla oldukça kolaylaşmıştır. Özellikle Facebook, kullanıcı sayısının çokluğu ve etkileşimli bir ortam olması nedeniyle bir e-kamusal alan olarak seçmenlerin seslerini duyurma olanağı sağlayıp, onlara birbirlerinin fikirlerini tartışma ortamı sunarak siyasete katılımlarını sağlaması nedeniyle siyasal iletişimde oldukça önemli bir araç olarak ön plana çıkmaktadır. Politik aktörlerin tek yönlü bir ileti aktarımına dayanan klasik siyasal iletişim eylemi yerine, çă̆ın dinamiklerini yansıtan Facebook gibi sosyal medya ortamları aracılığıyla etkileşimli bir siyasal iletişimi benimsemeleri ve bu gibi sosyal mecraları daha iyi anlayarak onları siyasal iletişim ve ikna stratejilerinin önemli parçaları haline getirmeleri siyasal iletişim başarısının anahtarıdır. Ayrıca politikacıların bunu gerçekleştirmeleri seçmenlerinin politik sürece katılımını önemsediklerini ve hatta siyasi mesajlarını bu ortamlardan elde ettikleri geribildirimlerle şekillendiklerini göstermeleri açısından da önem arz etmektedir.

\section{Kaynakça}

Akgün, B. (2008). "Küreselleşme, Bilgi Toplumu ve E-Demokrasi”. Medya ve Siyaset: Ed. Zülfikar. Damlapınar. Konya: Eğitim Kitapevi.

Aktan, E. (2017). Sosyal Medya ve Siyasal Katılım. Konya: Eğitim Yayınevi.

Aktaş, H. (2004). Bir Siyasal İletişim Aracı Olarak Internet. Konya: Tablet Kitapevi

Anık, C. (2000). Siyasal İkna. Ankara: Vadi Yayınları.

Aziz, A. (2003). Siyasal İletişim. Ankara: Nobel Yayın Dağıtım.

Berger, Arthur, A. (2000). Media and Communication Research Methods. London: Sage Publications.

Berger, Arthur, A. (1998). Media Research Techniques. London: Sage Publications.

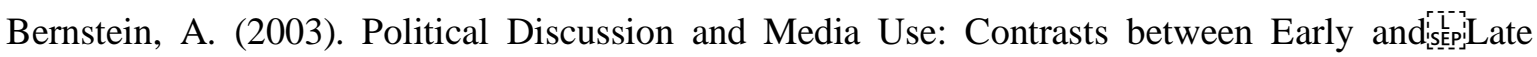
Campaign Phases. In: L. L.

Kaid vd. (eds.) The Millenium Election (Maryland: Rowman \& Littlefield Publishers, Inc), pp.. 217-232. 
Concordia. (2016). The Power of Big Data and Psychographics, https://youtube.com/watch?v=n8Dd5aVXLCc (23.05.2019).

Eser, H. B. \& Güler, Ö. (2015). "İnternet ve Sosyal Ağların Siyasal Katılım Üzerine Etkisi- SDÜ Örnek Olay1.” Mehmet Akif Ersoy Üniversitesi Sosyal Bilimler Dergisi, 7(12): pp. 196-219.

Göksu, V. (2016). Kamusal Alan ve Siyasal Katılma Mecrası Olarak Sosyal Medya. Konya: Çizgi Kitapevi.

İnce, M. (2019). "Bir Dönemin Resmi;1971-1980 Yılları Arasında Liderlik, Söylem, İmaj ve Basına Genel Bakış". Türkiye'de Basından Medyaya Değişim, Dönüşüm ve Modernleşme, Ed. Uğur Gündüz, Konya: Çizgi Kitapevi.

İnce, M. (2016) Spor ile Siyasetin İlişkisi Üzerine Bir Analiz; Sporu Siyasete Alet Etmek, Karabük Üniversitesi Sosyal Bilimler Enstitüsü Dergisi, Cilt 6, Say1 2, 447-455

Konfüçyüs (2017). Hayat Mutsuz olmak Iç̧in Çok Kısa. İstanbul: Aylak Adam Kültür Sanat Yayınc1lik.

Matz, C. S., Kosinski, M., Nave, G., \& Stillwell, D. (2017). "Psychological Targeting As An Effective Approach To Digital Mass Persuasion." https://www.pnas.org/content/114/48/12714(2019).

McNair, B. (2003). An Introduction to Political Communication. London: Routledge.

Milliyet.com.tr (2018). “Türkiye'nin Sosyal Medya Karnesi Açıklandı." http://www.milliyet.com.tr/turkiye-nin-sosyal-medya-karnesi-internet-haber-2763053/ e.t: 2019.

Montaigne, M. (2017). Yavaşladıkça Çoğalıyorum. İstanbul: Aylak Adam Kültür Sanat Yayıncılık.

Nurluoğlu, G. (2019). "15 Maddede Türkiye'nin Dijital Tablosu: We Are Social 2019 Türkiye Raporu”. https://medium.com/@gamzenurluoglu/15-maddede-türkiyenin-dijital-tablosuwe-are-social-2019-türkiye-raporu-ebc034d01ef3/2019).

Örnek, M. (2016). “Etkileşim Oranı Nedir?”. https://pazarlamasyon.com/engagement-rateetkilesim-orani-nedir/(2019).

Özkan, A. (2004). Siyasal İletişim. İstanbul: Nesil Yayınları.

Sine, R., Sarı, G. (2018). "Profesyonel Gazetecilerin Gözünden Sosyal Medya ve Habercilik İlişkisi. "Akdeniz Üniversitesi İletişim Fakültesi Dergisi, 12(30), pp. 364-384. https://dergipark.org.tr/tr/download/article-file/626291(2019).

Rife, S.C., Cate, K., Kosinski, M. \& Stillwell, D. (2014). "Participant Recruitment and Data Collection Through Facebook: The Role of Personality Factors." https://www.researchgate.net/publication/270509852_Participant_recruitment_and_data_col lection_through_Facebook_the_role_of_personality_factors / 19.06.2019.

Türkiye İstatistik Kurumu. "Türkiye'nin İnternet Kullanım Alışkanlıkları." https://www.guvenliweb.org.tr/haber-detay/turkiyenin-internet-kullanim-aliskanliklari-tuik$2018 / 03.06 .2019$.

Yetişkin, E. (2016). "Sosyal Medya ve Stradanlaşan Gözetim.” Yeni Medya ve Toplum: Edt. A. Çağlar, Deniz. \& A. Banu, Hülür. Konya: Literatürk Akademia.

Perrealut, M.C., Mosconi, E. (2018). "Social Media Engagement: Content Strategy and Metrics Research Opportunities." https://www.researchgate.net/publication/322239820_Social_Media_Engagement_Content_ Strategy_and_Metrics_Research_Opportunities /18.06.2019. 